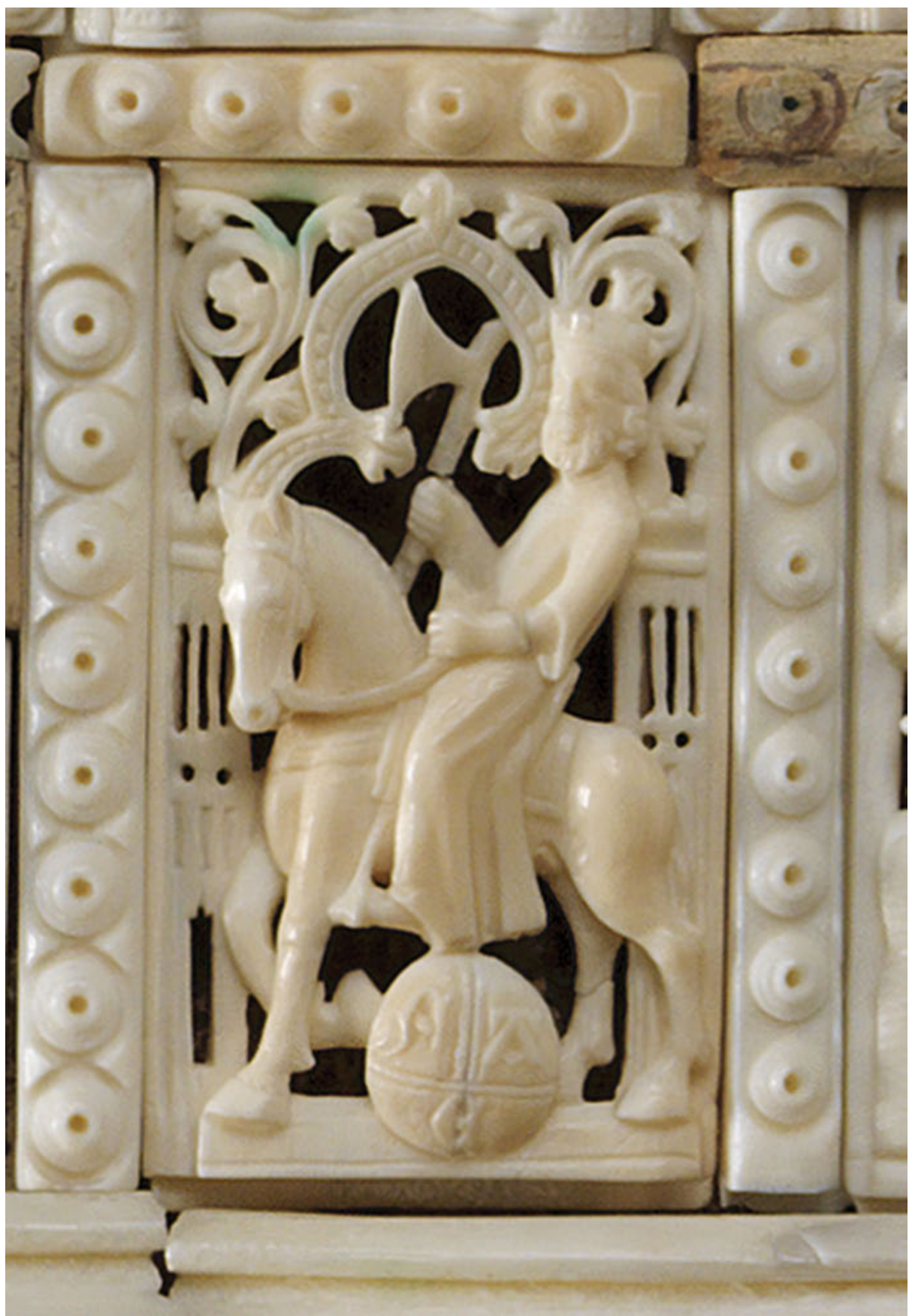

Fig. 1.1: St Olav, Rex perpetuum Norvegie, on horseback, with a T-O globe beneath his foot. Detail of portable ivory altar, early fourteenth century. Nationalmuseet, Copenhagen.

Ә Open Access. () 2021 Kristin B. Aavitsland, published by De Gruyter. (C) BY-Nc-ND This work is licensed under the Creative Commons Attribution-NonCommercial-NoDerivatives 4.0 International License.

https://doi.org/10.1515/9783110639438-002 


\section{Chapter 1 \\ Jerusalem: Navel of the Storyworld in Medieval Scandinavia}

Medieval Latin Christianity centred on Jerusalem - conceptually, devotionally, and often politically. The inclusion of the Scandinavian lands into Christendom provided the Northerners with new points of reference in space and time. Their new Christian horizon, or, as we prefer to label it, their Christian storyworld, came to frame the development of polities and institutions, of literary and material culture in this northernmost part of Europe. Actions and movements within this storyworld were often informed and motivated by what we conceive of as the Jerusalem code. ${ }^{1}$ This book is about the political, religious, and cultural workings of the Jerusalem Code in Medieval Scandinavia. It spans across almost five centuries and includes visual and literary material from Denmark, Sweden, Norway, and Iceland. It does not claim, however, to be comprehensive. Still, we consider it a valuable contribution not only to the historiography of medieval Scandinavia, but also to the international scholarly exploration of Jerusalem reception in medieval Europe, which has been going on for some years. ${ }^{2}$ The present introduction attempts to establish a conceptual and historical backdrop for the rich and varied manifestations of the Jerusalem code presented in this volume. The longevity of the Jerusalem code beyond the Middle Ages is explored in two additional volumes. ${ }^{3}$

\footnotetext{
1 For definitions of storyworld and Jerusalem code, fundamental concepts to this volume and the two subsequent volumes in this series, see Prelude, 6-8.

2 See for instance Annette Hoffmann and Gerhard Wolf, eds., Jerusalem as Narrative Space/ Erzählraum Jerusalem (Leiden - Boston: Brill, 2012); Lucy Donkin and Hanna Vorholt, eds., Imagining Jerusalem in the Medieval West, Proceedings of the British Academy (Oxford: Oxford University Press, 2012); Bianca Kühnel, Galit Noga-Banai, and Hanna Vorholt, eds., Visual Constructs of Jerusalem, CELAMA (Turnhout: Brepols, 2014); Renana Bartal and Hanna Vorholt, eds., Between Jerusalem and Europe: Essays in Honour of Bianca Kühnel (Leiden: Brill, 2015).

3 The two subsequent volumes of Tracing the Jerusalem Code: Volume 2: The Chosen People. Christian Cultures in Early Modern Scandinavia (1536-c.1750), ed. Eivor Andersen Oftestad and Joar Haga; Volume 3: The Promised Land. Christian Cultures in Modern Scandinavia (c.1750-c.1920), ed. Ragnhild J. Zorgati and Anna Bohlin.
}

Kristin B. Aavitsland, Professor of Medieval Studies, MF Norwegian School of Theology, Religion and Society, Oslo, Norway 


\section{Kringla heimsins: The Scene of Salvation History}

About 1230 the Icelandic author, law speaker, and erudite man of letters, Snorri Sturluson (1178/9-1241) set out to write a chronicle of the Norwegian kings. He opened his narrative with the following paragraph:

The disc of the world that mankind inhabits is very indented with bays. Large bodies of water run from the ocean into the land. It is known that a sea extends from Norvasund (the Straits of Gibraltar) all the way to Jórsalaland (Palestine). From the sea a long gulf called Svartahaf (the Black Sea) extends to the north-east. It divides the world into thirds. To the east is the region called Asia, and to the west some call Europe, and some Enea. And from the north of Svartahaf extends Svípjód in mikla (Sweden the Great) or in kalda (the Cold). Some claim Svípjóð to be smaller than Serkland it mikla (Saracen-land the Great, North Africa); others compare it to Bláland it mikla (Blacks-land the Great, Africa). The northern part of Svípjóð remains uninhabited because of frost and cold, just as the southern part of Bláland is empty because of the heat of the sun. In Svípjóð there are many large uninhabited areas. There are also nations of many kinds and many languages. There are giants there and dwarfs, and there are black people there, and many kinds of strange nations. There are also amazingly large wild animals and dragons. ${ }^{4}$

It emerges that Snorri Sturluson begins his history of the Norwegian kings with a description of the world - or rather, a description of the inhabited lands, the oikumene. In doing so, he follows a well-established Christian convention. From patristic times, the terrarum orbis - in Snorri's vernacular: the kringla heimsins - was conceived of as the unity of the three continents Europe, Asia, and Africa (the latter dubbed Serkland and Bláland in Snorri's terminology). The division of the world in three continents occurs in the writings of both Jerome and Augustine, and most medieval authors inherited it as an undisputed given. Snorri describes the inhabited world according to this conventional scheme, in which the Mediterranean and the Black Sea separate the three continents, and Jorsalaland, the land of Jerusalem, occupies the central point in between them. ${ }^{5}$ Since Late Antiquity, this scheme had been visualized as a

4 "Kringla heimsins, sú er mannfólkit byggir, er mjök vágskorin; ganga höf stór or útsjánum inn í jörðina. Er pat kunnigt, at haf gengr frá Nörvasundum ok alt út til Jórsalalands. Af hafinu gengr langr hafsbotn til landnorðrs, er heitir Svartahaf; pat skilr heimspriðjungana: heitir fyrir austan Asía, en fyrir vestan kalla sumir Európa, en sumir Enea. En norðan at Svartahafi gengr Svípjóð hin mikla eða hin kalda; Svípjóð hina miklu kalla sumir menn eigi minni en Serkland hit mikla, sumir jafna henni við Bláland hit mikla. Hinn nörðri hlutr Svíbjóðar liggr úbygðr af frosti ok kulda, svá sem hinn syðri hlutr Blálands er auðr af sólar bruna. Í Svíbjóð eru stórheruð mörg, par eru ok margskonar pjóðir ok margar tungr: bar eru risar ok par eru dvergar, par eru ok blámenn, ok par eru margskonar undarligar bjóðir, par eru ok dýr ok drekar furðuliga stórir,” Snorri Sturluson, Heimskringla, 3 vols, trans. Alison Finlay and Anthony Faulkes, London: Viking Society for Northern Research, University College London, 2016, vol. 1, Ynglinga saga, ch. 1.

5 Snorri distinguishes between habitable and inhabitable zones of the world, and hence reflects the concept of climate zones, prominent in medieval cartography, see for instance Stefan Schröder, "Die Klimazonenkarte des Petrus Alfonsi. Rezeption und Transformation islamisch-arabischen Wissens im 
circular diagram, the so-called T-O map. About 600, Isidore of Seville (c.560-636) famously applied this simple graphical form in his widespread, encyclopaedic compilation Etymologiae, a work that left its firm stamp on numerous texts in Old Norse. It reflected both Jerome's and Augustine's mutually independent descriptions of the three continents of the world. ${ }^{6}$ In medieval culture the T-O map became an abbreviated and widely used sign for the oikumene, applied not only as diagrams in codices but also in the iconography of Christian rulership (Fig. 1.1). ${ }^{7}$

Jerome and Augustine's interest in the oikumene was exegetical. In the biblical language of the Vulgate, the created world - mundus or saeculum - is the scene on which the history of humankind unfolds. Implicit in this conception of the world, and especially evident in the term saeculum, is the unity of time and space. The finite, created cosmos will cease to exist in its present form at the end of time, when the drama of salvation history reaches its end and human existence will transcend the limitations of time. Fines terrae, the ends of the world, should thus be conceived of as the spatial as well as the chronological limits of humankind. ${ }^{8}$ Accordingly, any historical narrative, like the Bible itself, should begin with a description of the extension of the oikumene, in order to set the scene, so to speak, for the stories to be told. ${ }^{9}$ Snorri Sturluson adopts this understanding when he finds it necessary to describe the whole of the inhabited world in the opening paragraph of his history of the Norwegian kings. The kringla heimsins comprises time and space at the same time: it is the Christian storyworld of medieval narrative, whose main point of orientation was Jórsalaland, the land of Jerusalem. ${ }^{10}$

In the eyes of thirteenth-century Icelanders like Snorri and the Norwegians who were his intended audience, as well as for contemporaneous Danes and Swedes, the Christian oikumene was an obvious framing for any tale to be told. The eleventh-century kings Snorri writes about, however, had struggled hard to familiarize themselves with this particular conception of time and space. Compared to the rest of Western Europe, the Nordic countries converted to Christian faith at a late stage. Scandinavians had been exposed to Christian practices, and even occasionally tended to conform to them, from the eighth century on. The first missionary campaigns to the north took place in the early eighth century, but were mostly met with aggression. Nevertheless, pagan Scandinavians conformed to Christian practices in

mittelalterlichen Europa," in Raumkonzepte: Diziplinäre Zugänge, ed. Ingrid Baumgärtner, et al. (Göttingen: V\&R Unipress, 2009).

6 For Jerome's formulation of Jerusalem as "umbilicus mundi," navel of the world, see Prelude, 5. 7 "die Erfassung und Schematisierung der Ökumene der klassischen Antike im Symbol der TOKarte [wird] zur Abbreviatur der bewohnten Welt,” Anne-Dorothee von den Brincken, Fines Terrae: Die Enden der Erde und der vierte Kontinent auf mittelalterlichen Weltkarten, MGH (1992), 3.

8 Brincken, Fines Terrae, 29.

9 "Die mitterlaterlichen Karten zeigen vor allem Land; Wasser interessiert weniger, da er selten Schauplatz des Heilsgeschehen ist,” Brincken, Fines Terrae, 28.

10 Cf. Prelude, 5. 
their settlements overseas; and there is evidence of Christian presence in the Scandinavian mainland as well. During the ninth and early tenth centuries, AngloSaxon and Continental missionaries came to Norway, Denmark, and Sweden, enjoying a certain success but providing no wide-ranging results. The definite shift came with the conversion of the ruling dynasties: In Denmark, King Harald Bluetooth (911-986) was baptized in the 960s. In Norway, King Olav Tryggvasson (963-1000) proclaimed Christianity in the 990s, followed by his successor King Olav Haraldsson (995-1030), who introduced Christian law in the second decade of the eleventh century, and was declared patron saint of Norway after his death. In Iceland, the chieftains assembled at the Alpingi of 999/1000 decided to embrace Christianity. The Faroes and Greenland adopted the new faith at about the same time. In Sweden, members of the ruling dynasty received baptism from c.1000 and onwards, but pagan practices lived on longer here than in the rest of Scandinavia. When the ruling houses of these countries permanently adopted the new faith, Christianity gained a secure foothold in the north, and by the end of the eleventh century, the "change of custom" [siðarskipti] was more or less completed. ${ }^{11}$

Pre-Christian Scandinavia was largely an oral culture. Literacy was introduced along with Christianity; hence Christian conversion implied not only a new cosmology and belief system, but also administrative, legislative, institutional, economic, and cultural transformation of the northern kingdoms. Literacy helped the Scandinavians to secure themselves a role in the history of salvation and a place in the realm of Christendom. The thirteenth century saw the culmination of what historians have described as the Europeanization of Scandinavia - the process by which the Scandinavian kingdoms became fully integrated in the culture of the Roman church and Latin Europe. ${ }^{12}$ Studies of Nordic texts on geography from the twelfth and thirteenth centuries show that medieval Scandinavians were self-consciously aware of inhabiting the margin. ${ }^{13}$ The Jewish-Christian notion of Jerusalem as the world's centre enforced this awareness of belonging to the periphery. When the

11 Dagfinn Skre, "Missionary Activity in Early Medieval Norway. Strategy, Organization and the Course of Events," Scandinavian Journal of History 23, no. 1 (1998). For general surveys of Scandinavian conversion history, see Richard Fletcher, The Barbarian Conversion from Paganism to Christianity (Berkeley: University of California Press, 1999), 369-416; Sverre Bagge, "Christianization and State Formation in Early Medieval Norway,” Scandinavian Journal of History 30 (2005).

12 Sverre Bagge, “The Europeanization of Scandinavia," in “The Making of Europe:" Essays in Honour of Robert Bartlett, ed. John Hudson and Sally Crumplin (Leiden - Boston: Brill, 2016).

13 Kristin B. Aavitsland, "Defending Jerusalem: Visualizations of a Christian Identity in Medieval Scandinavia,” in Visual Constructs of Jerusalem, ed. Bianca Kühnel, et al. (Turnhout: Brepols, 2014); Lars Boje Mortensen, "Sanctified Beginnings and Mythopoietic Moments. The First Wave of Writing on the Past in Norway, Denmark, and Hungary, c.1000-1230," in The Making of Christian Myths in the Periphery of Latin Christendom (c.1000-1300), ed. Lars Boje Mortensen (Copenhagen: Museum Tusculanum Press, 2006); Dale Kedwards, “Iceland, Thule, and the Tilensian Precedents,” Arkiv för nordisk filologi 130 (2015). 
Jerusalem code first was introduced in the North, it provided the Scandinavians with a productive network of metaphors, a comprehensive scaffold of poetically potent images, applicable to their efforts to inscribe themselves into the religious and cultural commonwealth of Christendom. An urgent issue for the northerners seems to be that of connecting to Jerusalem, the moral and eschatological navel of the Christian storyworld. ${ }^{14}$ This book aims to explore some of the ways in which medieval Scandinavians, living at the very brim of the kringla heimsins, related to its centre. ${ }^{15}$

\section{Transfer of Sanctity: Medieval Modes of the Jerusalem Code}

An obvious question to pose, then, is what kind of a centre Jerusalem was to medieval Europe - and to medieval Scandinavia. It was definitively not a political centre: never the capital of any empire, Jerusalem had no capacity to execute power over other territories. Nor was it an intellectual centre: it never housed any authoritative institution to which men of learning were attracted. Jerusalem's centrality was of a fundamentally different kind than that of closer centres with claims of influence over the Scandinavians, like Hamburg with its archbishop, Paris with its schools, or Rome with its canonists and ecclesiastical authorities. Jerusalem's lack of wideranging political and intellectual impact may indeed have prompted its significance as a conceptual and symbolic centre. From the point of view of the European margins in the eleventh century and onwards, "Jerusalem became the new center perhaps precisely because it could not claim any direct influence over the periphery," the historian Patrick Geary suggests. ${ }^{16}$ Jerusalem was The Holy City because it was the principal locus of divine intervention in human history, the universal axis mundi. Divine presence had sanctified the stones of Jerusalem and the very soil of the land, the Terra sancta. In a famous fourteenth-century English travelogue attributed to Sir John Mandeville, Jerusalem is described as a depot of sanctity, accumulated through the sacred events that had taken place there. In the words of Stephen Greenblatt, Mandeville's description of Jerusalem does not list these events in chronological order: "There is no sense of digging down through the sequential layers of the past, no historical framing. Instead there is a sense of semiological

14 Cf. Prelude, 8.

15 Aavitsland, "Defending Jerusalem," 121.

16 Patrick J. Geary, "Reflections on Historiography and the Holy: Centre and Periphery," in The Making of Christian Myths in the Periphery of Latin Christendom (c.1000-1300), ed. Lars Boje Mortensen (Copenhagen: Museum Tusculanum Press, 2006), 325. 
thickness, of opacity, of holiness solidified."17 How, then, was this semiological thickness that constituted the authority of Jerusalem mediated to the peripheral zones of Christendom? In other words, what were the medieval modes of the Jerusalem code?

To suggest an answer to these questions, it may be useful to remind ourselves of the pervasiveness and complexity that sanctity had imposed on the city. From Late Antiquity, Jerusalem had become the paradigm of the epistemological model of the quadriga, the fourfold interpretation of Scripture. ${ }^{18}$ It is significant that in medieval culture, the four levels of interpretation - the historical, the allegorical, the moral, and the eschatological - existed simultaneously and were equally valid. The historical city of Jerusalem, to which pilgrims flocked and for which crusaders fought, was conceptually integrated in the allegorical, moral and eschatological interpretations of the city. This holistic idea of Jerusalem made the place vitally significant not only to the course of salvation history, but also to the fate of the Church, the fate of humanity and the fate of each individual soul. Hence material traces, like relics commemorating Christ's passion, but also stones and even dust and mud from the city's ground, were tokens of the city's authority and, in a way, pledges of the validity of exegetical semiosis. Such material substances were portable, and they became the most potent medium to spread Jerusalem's sanctity to places far away, like the kingdoms at the brim of the kringla heimsins.

A late medieval, vernacular poem from Norway, "Forgive me, pure maiden" [Fyrirlát mér jungfrúin hreina], illustrates this point. It tells about how the cross went north - not by means of missionaries propagating a religious message, a moral codex, or a programmatic system of thought, as we moderns tend to define religion, but quite literally by means of a relic of the Holy Cross arriving from Jerusalem to Norwegian shores. ${ }^{19}$ As holy matter, relics connected to the passion of Christ transmitted the aura of the incarnate God. Christianity had not really arrived in Scandinavia until physical substance connected the land where Christ had suffered and resurrected with the lands in the north. Diffusion of Jerusalem relics remained an acknowledged medium to secure political legitimacy by referring to the divinely sanctioned status of Jerusalem. In two of the chapters in this book, Lukas Raupp and Lena Liepe explore the relations between royal power and Jerusalem relics in the three Scandinavian kingdoms. In the

17 Stephen Greenblatt, Marvellous Possessions: The Wonder of the New World (Chicago: University of Chicago Press, 1992), 39, my emphasis.

18 Cf. Prelude, 5-6.

19 The poem, which was largely forgotten after the Protestant reformation and survives in one single Icelandic manuscript, probably refers to the cross-relic King Baldwin of Jerusalem offered King Sigurd the Crusader in 1110. The relic finally ended up at the arch see of Nidaros, and was one among several passion relics arriving in Scandinavia during the Middle Ages. For the poem, see Jon Gunnar Jørgensen and Vésteinn Ólason, “'Tilgi meg, jomfru ren' - et norsk dikt fra senmiddelalderen,” in Atlantisk dåd og drøm, ed. Asbjørn Aarnes (Oslo: Aschehoug, 1998). 
twelfth century, relics connected to Jerusalem could compensate for weak dynastic claims to the throne, both in Denmark and Norway. ${ }^{20}$ In the thirteenth and fourteenth centuries, relics from Christ's crown of thorns were exchanged as gifts between monarchs and bishops in France, Norway, and Sweden, upholding the ideal of divinely sanctioned royal authority and promoting crusade as an aspect of the royal office. ${ }^{21}$

The palpable transfer of relics was one way of moving Jerusalem's sanctity to other places. Another was the conceptual transfer of sacrosanct authority. A basic precondition for what we could call the medieval paradigm of the Jerusalem code is the concept of translation - a medieval term used for any act of transfer, be it the shift of power from one polity to another [translatio imperii] or the ceremonial movement of relics from place to place. In her short comment on the translatio paradigm in the introductory section of this book, Eivor Andersen Oftestad presents the concept translatio templi to illustrate how religious authority in Europe was construed as historical transfer. ${ }^{22}$ From an early stage, Christian chroniclers and theologians in the West generally interpreted the Roman emperor's devastation of Jerusalem and destruction of the Jewish Temple in $70 \mathrm{CE}$ as an act of moving religious legitimacy from Jerusalem to Rome, and, consequently, from the Jews to the Christians. The idea of translatio templi is fundamental for Christian anti-Judaism and "othering" of the Jews. Moreover, it legitimized Christian use of Jewish models of authority, like the biblical kings, priests, and patriarchs. Several chapters in this book offer examples of legitimation of authority in medieval Scandinavia by appropriation of Jewish models.

Hence, connecting to Jerusalem meant translation of Jerusalem's sanctity, physically and conceptually. The Scandinavians learned to identify with and remember the Judeo-Christian past and the biblical landscapes through diverse strategies of translation, and thereby expanding their cultural memory vastly in time and space. ${ }^{23}$ The Danish medievalist Lars B. Mortensen has identified three modes by which medieval European peripheries created semiotic (semiological) relations between themselves and the biblical past, aiming to establish "meaning and coherence between new and old, local and foreign." ${ }^{24}$ In the context of this book, we may very well consider Mortensen's categories as modes of the Jerusalem code in medieval Scandinavia. Simultaneously, we expand Mortensen's scope, as he developed his model of understanding for the study of historiography and other literary genres that prevailed in the medieval North. However, his model is applicable also to visual sources, like ecclesiastical art and architecture. The medieval modes of the Jerusalem Code, hence, are fundamentally multi-medial.

20 Chapter 8 (Lukas Raupp), 140-65.

21 Chapter 9 (Lena Liepe), 166-87.

22 Chapter 3 (Eivor Andersen Oftestad), 49-55.

23 Jan Assmann, Religion and Cultural Memory. Ten Studies (Stanford CA: Stanford University Press, 2006), 7.

24 Mortensen, "Sactified Beginnings," 263. 
A first mode of semiotic connecting to Jerusalem would be imitation: That is to cast persons, events, and places in the North according to authoritative patterns found either in the Bible or in the history, topography, and architecture of Jerusalem and the Holy Land. A conspicuous instance of this is the literary representation of the saintly king Olav Haraldsson's re-entry to Norway after his conversion to Christianity and his victory at the battle at Nesjar, March 25, 1017. This event is praised in contemporary skaldic verse as well as in later chronicles. In his chapter, Bjørn Bandlien unveils ingeniously crafted semiotic imitation in these texts, as he shows how the battle at Nesjar is construed as the entry of Christianity to the kingdom of Norway on the template of Christ's entry in Jerusalem. ${ }^{25}$ Another intriguing example, also connected to St Olav, is the composite fabric of mimetic Jerusalem references in the urban layout and church buildings at Nidaros, the seat of the Norwegian archbishop, presented in Øystein Ekroll's chapter. ${ }^{26}$

A second mode of semiotic connection to Jerusalem is contact and contiguity: that is to establish material, ritual, and interpretative contacts in time and space, between the biblical past and the historical present. This is a way of empowering the lands in the North, which are situated far from the territories where the crucial events in salvation history took place. By emphasizing points of contacts in the biblical (and mythological) past as well as in the historical present, the Northerners could claim that they participated in the grand narrative of salvation history, and that they had always been part of the divine plan. Biörn Tjällén offers striking examples of this from late medieval Swedish hagiography and historiography. ${ }^{27}$

A third mode is creativity: the agency of the authors in selecting elements and build a composition (verbal, visual, or material) that conform to local as well as foreign conventions. An unusually rich composition of this kind is the thirteenth-century Icelandic Eyrbyggja saga of Thorolfr and his settlement at Thorsnes in Western Iceland, examined in Mikael Males' contribution. ${ }^{28}$ Set in a pre-Christian past, the narrative employs a selection of templates, topoi and singular motifs from Scripture as well as from pagan cultic practices in order to describe an age-old, holy topography in which the heathen past can be understood as a meaningful prefiguration of Christian salvation. Another creative structuring of sacred landscape is discussed in Kersti Markus' chapter on twelfth-century round churches in Västergötaland, Sweden. ${ }^{29}$

In the examples listed above, any one of the three modes of the Jerusalem code is especially striking. However, all three of them are at work at the same time. The "semiotic triangle" of imitation, contact, and creativity is, according to Mortensen,

25 Chapter 4 (Bjørn Bandlien), 59-85.

26 Chapter 19 (Øystein Ekroll), 270-98.

27 Chapter 24 (Biörn Tjällén), 520-33.

28 Chapter 21 (Mikael Males), 455-75.

29 Chapter 16 (Kersti Markus), 324-39. 
necessary components in the mythopoiesis - the creation of new myths. ${ }^{30}$ And this is exactly the means by which peripheries like Scandinavia connected to Jerusalem. Inclusion in the Christian oikumene was not about passive reception. Mythopoiesis stimulated local agency, "a creative localist response to external impulses." ${ }^{31}$ This is seen very explicitly in the narratives the Scandinavians established about their own conversion, as we will see in the following paragraphs.

\section{The Conversion of the Evil North}

As the Scandinavians embarked on the task of inscribing themselves into the history of salvation and define their place in the Christian storyworld, they entered a cultural sphere in which their regions were regarded as the abode of evil, and the Scandinavian peoples were considered diabolic. Partes aquilonis - the lands of the north wind - was the common designation of Scandinavia, from where early medieval Europe was used to expect little more than trouble, plundering and pillaging. ${ }^{32}$

The monks at Lindisfarne in 793 and the bishops in the realm of Charlemagne one generation later experienced highly unpleasant meetings with the heathen pirates from the north, and they found some kind of explanation in biblical exegesis. ${ }^{33}$ In the book of Jeremiah, the Lord declared, "out of the north evil shall break forth upon all the inhabitants of the land" (Jer 1:14). Furthermore, the prophet himself begged the people of Jerusalem to "flee for safety [. . .], for evil looms out of the north, and great destruction" (Jer 6:1). Another of the great Old Testament prophets, Isaiah, claims that Lucifer, "the king of Babel," plans to rise from his abode in the north to challenge God, but shall be defeated (Isa 14:13-14). In the Song of Songs, the life-giving southern wind, auster, is contrasted with the freezing northern wind, aquilo (Cant 4:16). In early medieval exegetic commentaries and historiographies, these passages from Scripture were combined and merged with the classical authors' descriptions of the exotic, alien and even monstrous peoples and animals in the distant Hyperborean. ${ }^{34}$ The result was a comprehensively negative notion of the

30 Mortensen, “Sactified Beginnings," 256-66.

31 Mortensen, "Sactified Beginnings," 269.

32 Vegard Skånland, “Calor Fidei," Symbolae Osloenses 32 (1956). Conceptions of the North in classical and medieval continental literature are examined extensively in the recent volume by Dolly Jørgensen and Virginia Langum, eds., Visions of North in Premodern Europe, CURSOR MUNDI (Turnhout: Brepols, 2018).

33 Skånland, "Calor Fidei," 98-99.

34 Pliny, Naturalis Historia et al. Cf. Lewis Webb, "Inter imperium sine fine: Thule and Hyperborea in Roman Literature," in Visions of North in Premodern Europe, ed. Dolly Jørgensen and Virginia Langum (Turnhout: Brepols, 2018); Mirela Avdagic, "The North in Antiquity: Between Maps and Myths," in 
North, which medieval authors even explicitly contrasted with Jerusalem through allusions to Isaiah's mention of Babel.

By the eleventh and twelfth centuries, when the Scandinavians eventually acquired and cultivated a Christian outlook of the world, the conception of the diabolic and monstrous North necessarily was a part of that outlook. Consequently, it came to influence the way Scandinavians considered their own conversion. Understood as territories, aquilo represented the heathen lands, whereas auster represented Christendom. As mission advanced, aquilo's frontier was gradually pushed back and further out towards the periphery. Since auster and aquilo were also understood as proper winds, the association to breath and spirit was close at hand. The freezing aquilo then becomes the spirit of evil, contrary to the warm and tender auster which of course is associated with the Holy Spirit. The glacier of infidelity, glacies infidelitas, had to be melted down by the heat of faith, calor fidei. These tropes prominently occur in the Passio Canuti regis, an account of the Danish royal saint King Knud (c.1043-1086), written about 1122. About the same time, Peter the Venerable (1092-1156), famous abbot of Cluny, applies them in his letter to King Sigurd Magnusson of Norway (1090-1130), encouraging his plans for a missionary campaign to Sweden. ${ }^{35}$ In the second half of the twelfth century, the same tropes are found in Latin historiography written at the arch see of Nidaros in Norway. ${ }^{36}$ Up until the fourteenth century, Scandinavian authors continued to adapt the figurative language of the biblical North and apply it when writing their own history. Indeed, it was interpreted as scriptural mentions of the Scandinavian countries, constituting semiotic contact between the biblical past and the Nordic present. ${ }^{37}$ The conception of the evil north helped the Scandinavians explain why it had taken such a long time before Christian faith arrived at their shores.

Such strategies inscribed the lands in the north into the storyworld of salvation history, and are related to a central concept in the history of Christianity and a driving force in what we have labelled the Jerusalem code, namely the notion of being God's elect people. This notion is an extremely flexible one, and it has informed the group identity of almost every European Christian nation at some point in their history. As Mary Garrison has pointed out, the idea of divine election enables any people converted to Christianity, no matter how distant in time and space from Jerusalem and the age of the apostles, to "affirm their own specialness on a yardstick of ultimate

Visions of North in Premodern Europe, ed. Dolly Jørgensen and Virginia Langum (Turnhout: Brepols, 2018).

35 Skånland, "Calor Fidei," 86-7.

36 Steffen Hope, "The North in the Latin History Writing of Twelfth-Century Norway," in Visions of North in Premodern Europe, ed. Dolly Jørgensen and Virginia Langum (Turnhout: Brepols, 2018), $116-17$.

37 Cf. Mortensen's category explained above, 20. 
meaning." ${ }^{38}$ By emphasizing their specialness in their inclusion into the oikumene of Christendom, Christian northerners were able to demarcate themselves from their non-elect, still heathen neighbours, as Margrethe C. Stang shows in her chapter on the representation of otherness in ecclesiastical art from medieval Norway. ${ }^{39}$

In Scandinavian medieval historiography, the narrative motor of which is the gradually advancing conversion process, the notion of election or specialness is used, somewhat paradoxically, to secure universalism and inclusion in the commonwealth of Christians. ${ }^{40}$ A learned example is found in the oldest historical account of Norwegian history, the anonymous Historia Norwegie, dated to the second part of the twelfth century. ${ }^{41}$ Here, the coastal zone of southern and western Norway is called Decapolis (ten cities), "because it is renowned for its ten townships." 42 As several scholars have noted, this obviously refers to the Gospel, where Decapolis is mentioned trice as name of a geographical region in Galilee (Matt 4:25; Mark 5:20 and 7:31). ${ }^{43}$ Its ten towns, which enjoyed a certain degree of autonomy, had a mainly Greek population. The crowds gathering around Jesus, as he took up his mission of teaching and healing, came primarily from these areas in the "Galilee of the Gentiles." Decapolis is thus associated with conversion, and this may be why the author of Historia Norwegie parallels the district with the coastal area of Norway. As he does not name the ten townships in his Norwegian Decapolis, historians have come up with alternative lists of towns along the coast. ${ }^{44}$ The rhetorical point here is, however, not the precise identity of these "townships." Rather, this instance of semiotic imitation holds a theological significance that seems to be lost on most modern commentators. What justifies the translation of the Decapolis from the Mediterranean to the North Sea is the pagan

38 Mary Garrison, "Divine Election for Nations - a Difficult Rhetoric for Medieval Scholars?," in The Making of Christian Myths in the Periphery of Latin Christendom (c.1000-1300), ed. Lars Boje Mortensen (Copenhagen: Museum Tusculanum Press, 2006), 277.

39 Chapter 22 (Margrethe C. Stang), 477-99.

40 The flexible notion of specialness and divine election may very well also serve the opposite: particularism and even chauvinism, cf. Garrison, “Divine Election,” 278.

41 The author, date and provenience of this text is not known. In his edition of the text, Lars Boje Mortensen suggests that the book, incomplete in its present state, was written in Eastern Norway c.1160-75, cf. Historia Norwegie, trans. Peter Fisher, ed. Lars Boje Mortensen and Inger Ekrem, Copenhagen: Museum Tusculanum Press, 2003.

42 "Zona itaque maritima Decapolis dici potest, nam x ciuitatibus inclita est," Historia Norwegie, $54-5$.

43 The term, which is also found in Pliny's Naturalis historia (5.16.74), referred to the area on the east and south-east of the Sea of Galilee.

44 See for instance Frode Iversen, "The Urban Hinterland: Interaction and Law-Areas in Viking and Medieval Norway," in Viking-Age Transformations: Trade, Craft and Resources in Western Scandinavia, ed. Zanette T. Glørstad and Kjetil Loftsgarden (London - New York: Routledge, 2017), 254. 
character of this district. ${ }^{45}$ A strong current in medieval exegesis emphasizes that Jesus first chose to evangelize in the "Galilee of the Gentiles," and hence the gentiles were converted from outside the Hebrew tradition, without taking part in the Old Covenant and obeying the Mosaic Law. When the anonymous author of Historia Norwegie lets the coast of Norway mirror Galilee, he creates a historical typology. Just as the Gentiles in Decapolis had no need of the Hebrew tradition to be converted, the heathens of the North have no need of a long Christian past in order to become incorporated in the grand master narrative of salvation history. By transporting the topography of Palestine to the Norwegian coast, the author inscribes Norway into the Christian storyworld. Hence, the very country is now defined by its separation from heathendom: "On the borders of Norway is an immense wilderness, which divides the country along all its length and separates the Norwegians from the heathens," the author of Historia Norwegie claims. ${ }^{46}$

Through texts like this, and through a range of mimetic cultural and religious practices, Jerusalem and the Holy Land became familiarized as the far-away topographical and moral centre of the world - the axis mundi.

\section{The Jerusalem Code at Work: Touring the Storyworld}

The twentieth-century Canadian literary critic Northrop Frye (1912-1991) considered biblical language a code to Western literature in a manner similar to our considering the idea of Jerusalem a code to Christian cultures in Scandinavia. ${ }^{47}$ In his 1981 book The Great Code, Frye read the Bible as a body of mythological stories that informed the great tradition of Western literature. In this book, Frye points out that the Old Testament myths of the Children of Israel tend to share a common storyline:

The heavy emphasis on the structure, where because of the moral interest we are in effect being told the same kind of story over and over again, indicates that the individual stories are being made to fit that pattern. [. . .] The priority is given to the mythical structure or outline of the story, not to the historical content. ${ }^{48}$

This insight seems to be valid also for extra-biblical mythologies in premodern Christianity. The grand narrative of salvation history, emerging from medieval exegesis, exhibits a narrative template, a mythical macrostructure of fall, retribution

45 I wish to thank Mr. Eirik A. Steenhoff for drawing my attention to this point, and for stimulating conversations about this issue.

46 "Est igitur vastissima solitude affinis Norwegie dividens eam per longum a paganis gentibus", Historia Norwegie, 58-9.

47 Cf. Prelude, 3.

48 Northrop Frye, The Great Code: The Bible and Literature (New York - London: Harcourt Brace Jovanovich Publishers, 1982), 41. 


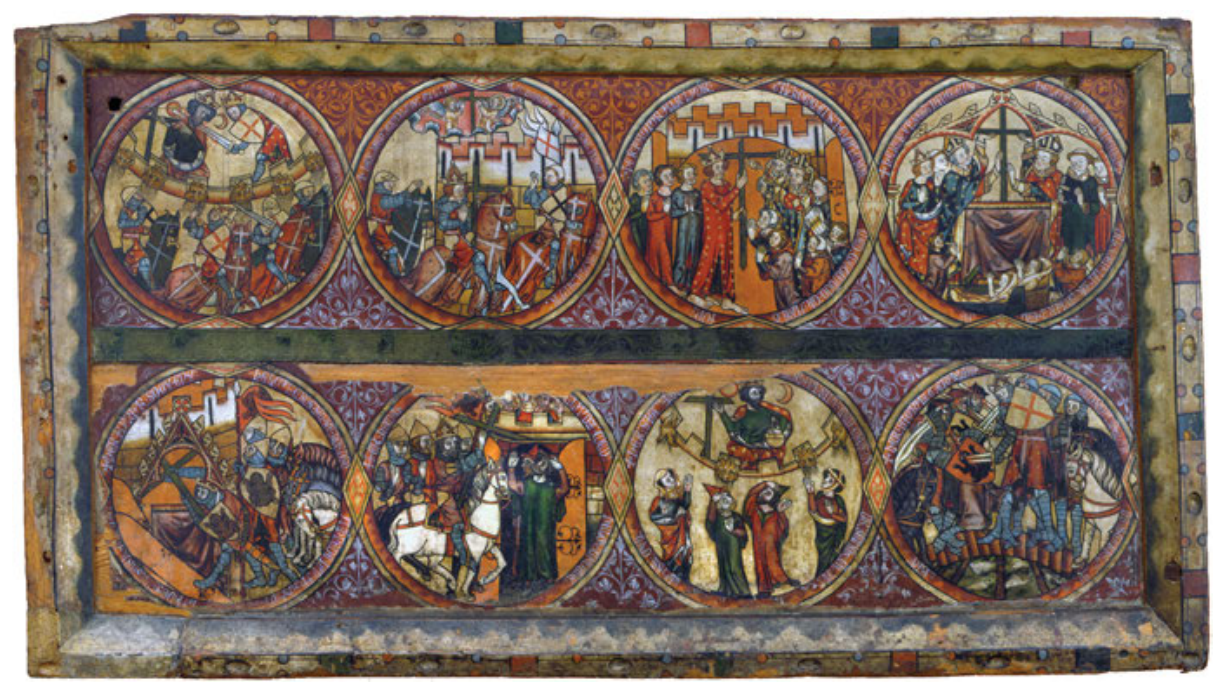

Fig. 1.2: Scenes from the Exaltation of the Holy Cross. Altar frontal from Nedstryn Church, Western Norway, 1300-1325. University Museum of Bergen.

and redemption which eminently conditions the Jerusalem code and shapes the Christian storyworld.

In the introductory Prelude to this volume, we listed a set of binary categories which seem to coordinate the movements taking place in this storyworld: Jerusalem/ Babylon, legitimate/illegitimate rulership, faith/infidelity, virtue/vice, God/world, life/death. ${ }^{49}$ Together with the mythical macrostructure, these antithetic pairs are components in a dominating mind-set that came to inform political action as well as cultural production in Christian medieval cultures. We claim that a more or less sophisticated conception of this storyworld was an essential and inevitable precondition for medieval Scandinavians' engagement with Jerusalem, be it as travellers, pilgrims, crusaders, political agents, cloistered intellectuals, or lay churchgoers.

To illustrate how the Jerusalem code may work according to these principles, I will give an example of elaborate visual storytelling from medieval Norway: an altar frontal dating from around 1300, probably made in Bergen, the largest and most prominent of Norwegian towns in the Middle Ages. The altar frontal exhibits the legend of the Exaltation of the Holy Cross in a particularly elaborate manner (Fig. 1.2). It came to the medieval collection of the university museum in Bergen from Nedstryn

49 Prelude, 8. 
Church, a small parish church in Western Norway; but as several scholars have argued, this was probably not its original context. Rather, the panel seems to have been made to adorn the altar of the Church of the Apostles in Bergen. This was royal chapel built by King Magnus VI Haakonsson (1238-1280), allegedly in order to house the precious gift he had received from King Philip III of France in 1274: a thorn from Christ's crown of thorns. ${ }^{50}$ This relic of course constitutes a material link between Jerusalem and the North, as does the story visualized in the altar frontal, about Emperor Heraclius conquering Jerusalem and rescuing the Holy Cross. The story was known in Scandinavia from different sources, but remarkably in this context, around 1300, the royal court in Bergen possessed a prominent version of it originating in the crusader states of the East. An Old French illuminated manuscript produced in the crusader principality of Antioch around 1260 and containing the story of Heraclius was demonstrably in the ownership of Queen Isabella Bruce of Norway (1272-1358). ${ }^{51}$ She resided in Bergen from 1293 until her death in 1358, and she may even have witnessed the production and installation of the altar frontal.

The frontal ingeniously exhibits the binary categories and the narrative template of the Jerusalem code mentioned above. The story presented here is a blend of history and myth, beginning with Chosroes II (579-628), the last king of the Sassanian Empire before the Muslim conquest of Iran. He led a devastating war against the Byzantine emperor Heraclius (610-641), and conquered Jerusalem in 614. In the mythical rendering of what happened next, the precious relic of the Holy Cross, recovered three centuries earlier by Empress Helena (c.246-c.330), was taken as booty. In vain triumph, King Chosroes took the Holy Cross to his capital Ctesiphon, where he became so proud of his victory that he had a tower built with a vault imitating the celestial bodies, took seat there orchestrating himself as a cosmic ruler, and made his people hail him as a god. These events are depicted in the four lower medallions of the Nedstryn altar frontal. ${ }^{52}$

Emperor Heraclius initiated several successful campaigns against the Sassanian king, defeating his son in battle, and then advancing to the mock heaven on top of Chosroes' tower, where he slaughtered the king after his refusal to convert to the Christian faith. The victorious emperor then intended to bring the Holy Cross back to its right place in Jerusalem, but he was not able to enter the city gate, which

50 Cf. above, 19. For the royal relic gift and the Church of the Apostles, see Chapter 9 (Lena Liepe), $168-77$.

51 In addition to the Heraclius story, the manuscript also contains William of Tyre's chronicles about Jerusalem and the Holy land. On the manuscript and its royal, Norwegian ownership, see Bjørn Bandlien, “A Manuscript of the Old French William of Tyre (Pal. Lat. 1963) in Norway,” Studi mediolatini e volgari 62 (2016).

52 It is worth noting that in the Old Norse rendering of this legend, Chosroes is a Saracen (Muslim) ruler, not a Persian. For further discussion of the Nedstryn altar frontal, see Chapter 22 (Margrethe C. Stang), 480-83. 
miraculously disappeared in front of him. An angelic apparition teaches him a lesson, reminding him of a greater king who had entered this very gate before, not dressed in armour and with royal pomp, but humble and unarmed on the back of an ass. As Heraclius then leaves his horse behind and enters the city barefoot, the gate now opens to him. And as the Holy Cross is reinstalled on the altar in the church of the Holy Sepulchre, miracles of healing and resurrection are reported. This is what is happening in the four upper medallions of the frontal.

The fundamental storyline here is almost universal: the order of things is disturbed and has to be restored. This is, of course, a storyline shared with the master narrative of salvation history: injustice has to be recompensed. In this story, Jerusalem is the setting: It is the site where the Holy Cross was sanctified by Christ's passion and thus where it rightly belongs, and the story is completed on its return to this site. But Jerusalem is also, besides Chosroes and Heraclius, an acting protagonist. Being violated after Chosroes' sacrilege in the beginning of the story, she turns into action by hiding her gates for yet another armed king blinded by his own pride. When Heraclius puts down his weapons and approaches her gently, she lets him in. The whole biblical cluster of metaphors about the Daughter of Zion and Jerusalem adorned as a bride inevitably comes into play here.

In the Nedstryn altar frontal, the order of "reading" the eight figure medallions is not what we would expect for a straightforward, linear account of the narrative (as in a book), as the lower row of images is to be "read" before the upper. But according to the conventions of visual rhetoric, this order is quite logical: The four scenes with Heraclius, who is the story's hero, have to be placed above the villain Chosroes, despite the fact that he is the main protagonist in the first portion of the narrative. The composition of the altar frontal also brings all the binary categories of the Jerusalem Code to the fore. By pairing the medallions vertically, the opposition between the actions and their consequences become evident: The crime of Chosroes has to be punished, and the triumph of the illegitimate ruler is contrasted by the triumph of the legitimate one. The pride (cardinal vice) of Chosroes is juxtaposed by the humility (cardinal virtue) of Heraclius, and finally, the defeat and subsequent death of the Sassadian army (= the children of the world) contrast the resurrection of the Jerusalemites (=the children of God), hence foreshadows the fate of the just and unjust at the Final Judgement.

The contrast between the city of Jerusalem and Chosroes' capital Ctesiphon is also suggested here - Ctesiphon is perhaps vaguely associated with Babylon, the paradigmatic metropolis of the east. Yet another compositional aspect contrasts the two rulers of this narrative by alluding to some of the storyworld's major visual tropes: The contrast of the pagan and the Christian king is enhanced by alluding to the imperial adventus imperatoris (Chosroes on horseback) against the biblical adventus Domini (Heraclius on foot). Finally, Chosroes' sporting of the cross as a magical device testifies to his pagan idolatry, whereas the Christians adore the cross as a manifest witness to God's sacrifice and hence demonstrate true devotion. In this 
way, the very design of the altar frontal produces a dense fabric of didactic, moral, and cultic meaning by means of the Jerusalem code. If we are right to assume that its original setting was the royal chapel housing a thorn from Christ's Holy Crown, the story's authority was enforced by the presence of the Jerusalem relic.

\section{Scandinavians in Medieval Jerusalem, c.1000-c.1500}

The interpretative strategies of the Nedstryn frontal and in the other textual and visual examples presented above were nurtured by actual travel from the Nordic countries to the Eastern Mediterranean and Jerusalem during the medieval centuries. The first traces of contact between Scandinavia and the oriental world are imported Byzantine artefacts in Scandinavian (Swedish) graves from the ninth century. Travel to and trade with the Greek and Muslim world continued in the following centuries, as archaeological finds affirm. Moreover, a number of eleventh-century rune stones spread all over Scandinavia carry inscriptions about men who died on expeditions to Serkland (Saracen-land). ${ }^{53}$ From the late tenth century and well into the twelfth, a considerable number of Norsemen served as mercenaries in the imperial palatine force in Constantinople, the so-called Varangian guard. ${ }^{54}$ In Norse tongue, Constantinople was dubbed Miklagard, The Great City. In the eyes of the travellers from the north, Miklagard in all its imperial glory clearly outshone Jerusalem, which, however holy, remained a minor city in the periphery of the Fatimid caliphate. Practical experience hence contradicted the conceptual and theological centrality of Jerusalem. Yet, a certain urge to go there on pilgrimage may be discernible among Scandinavians in the eleventh century. A case in point could be the already mentioned king and future saint Olav Haraldsson, who purportedly intended to travel to Jerusalem around 1013, but turned home instead to fight for his ancestral lands. Although Olav's aborted pilgrimage may be dismissed as a construction by thirteenth-century chroniclers, it is not at all improbable that a highborn man-at-arms like him, widely travelled and well versed in international politics, had a desire to see Jerusalem at the beginning of the eleventh century. In the wake of the millennium shift, the city saw an increasing number of Western pilgrims

53 Else Roesdahl, Vikingernes verden. Vikingerne hjemme og ude (Copenhagen: Gyldendal, 1993), 315; Kurt Villads Jensen, Crusading at the Edges of Europe: Denmark and Portugal c.1000-c.1250 (London: Routledge, 2016), Chapter 3, note 131.

54 Roland Scheel, Skandinavien Und Byzanz: Bedingungen Und Konsequenzen Mittelalterlicher Kulturbeziehungen, 2 vols., Historische Semantik (Göttingen: Vandenhoeck Ruprecht, 2015), vol. 1, 77-291. 
fuelled by eschatological expectations. ${ }^{55}$ As Bjørn Bandlien argues in Chapter 4, the earliest literary representations of King Olav Haraldsson's authority were indeed fashioned by current eschatological ideas, like the prophecy about the Last Emperor who would defeat Antichrist in Jerusalem at the end of time. ${ }^{56}$

The first crusade (1095-1099) and the Frankish conquest of Jerusalem fundamentally affected Europe's relation to The Holy Land, and the Europeans' relation to the Jewish, Muslim, and oriental Christian population living there. This was also true of Scandinavia. As independent church provinces were established in the North during the twelfth century, the idea of just war against heathens came to play a determining role for ecclesiastical politics. Moreover, the literate culture and religious practices thriving in these young church provinces was also highly influenced by crusade ideology - as several of the contributions to this book clearly show. From the very beginning, the Scandinavian elites were well informed about Pope Urban's initiative, and they seem to have found themselves ideologically obliged to support it. ${ }^{57}$ Contemporary Nordic and Continental sources testify that Danes and Norwegians participated perseveringly in the violent conquest of Jerusalem in 1099. Among them was allegedly a young prince called Svend, said to be one of King Svend Estridsen' many sons and to have been killed by the Seljuk sultan's army on his way to the Holy City. ${ }^{58}$ The martyr-like death of the Danish prince immortalized his memory and spun him into a web of chivalric myth, which peaked in Torquato Tasso's epic poem Gerusalemme liberata more than five centuries later (1581). ${ }^{59}$

After Godfrey of Bouillon's establishment of the Latin Kingdom of Jerusalem in 1099, sources to Scandinavian presence in Palestine become more numerous and reliable. Two Scandinavian kings were among the first Western sovereigns to pay tribute to Godfrey's successor, King Baldwin I of Jerusalem (1058-1118). King Erik the Good of Denmark (c.1056-1103) set out together with his queen Bodil Thrugotsdaughter (c.1056-1103), but died en route on Cyprus. Queen Bodil continued the journey, reached the Holy City, and died on the Mount of Olives soon after her arrival in 1103. The already mentioned Norwegian king Sigurd Magnusson went a few years later, with a large fleet of crusaders. He reached Palestine in 1110 and offered military support to King Baldwin in his efforts to expand the borders of his realm. King Sigurd's expedition earned him the epithet "Jerusalem-traveller" or simply “Crusader" [Jórsalafari].

The royal crusades from Denmark and Norway paved the way for further Scandinavian pilgrimage and crusading during the twelfth and thirteenth centuries.

55 Karen Armstrong, Jerusalem: One City, Three Faiths, Random House Publishing Group (New York: Random House Publishing Group, 2011 [1997]), 266.

56 Chapter 4 (Bjørn Bandlien), 71-6.

57 Jensen, Crusading at the Edges of Europe, 50.

58 Jensen, Crusading at the Edges of Europe, 139.

59 See Janus Møller Jensen's contribution to Tracing the Jerusalem Code, vol. 2, 198-231. 
Minor expeditions left Scandinavia and the Norwegian settlement at Orkney in the following decades. Travel from the brim of the kringla heimsins to its centre remained, however, an elite phenomenon, not least because of the enormous costs of the journey. In 1153, Rognvald, Earl of Orkney (1103-58) organized a campaign on a larger scale together with the magnate Erling Ormsson (1115-79), King Sigurd's son-in-law. Pål Berg Svenungsen discusses this Orcadian crusade in his chapter, showing how the Norse elites developed what may be called a crusading spirit in the aftermath of the First Crusade, and how crusading became a means to consolidate political and ideological power at home. ${ }^{60}$ At the time of Rognvald and Erling's crusade, the Church of the Nativity in Bethlehem was adorned with frescoes of St Knud and St Olav, the royal patron saints of Denmark and Norway. This testify to diplomatic connections between the Kingdom of Jerusalem and the Scandinavian countries in the period. Øystein Ekroll presents these images as a palpable demonstration of the inclusion of the Nordic countries in the oikumene of Christendom. ${ }^{61}$

From the twelfth to the fourteenth and fifteenth century, Scandinavian travellers to Jerusalem, whether they be kings or commoners, lay or clergy, pilgrims or crusaders, seem to have shared certain practices common for western visitors. Their emotional responses at the sight of the city from afar: rejoicing, weeping, or both, tend to conform to the reactions prescribed by former authoritative visitors to Jerusalem, biblical and extra-biblical. Anthony Bale provides examples for this in his short chapter on Mons Gaudii or Mount Joy, the hilltop from where pilgrims first got a glimpse of their destination. ${ }^{62}$ Arriving in Jerusalem, twelfth-century travellers came to in a city that had reached a certain level of prosperity and flourishing under King Baldwin's rule, despite the desolation and ruin that followed the extreme violence of the Franks' conquest in 1099. During the first half of the twelfth century, the Franks transformed "a provincial Muslim city into the capital of a Western Christian kingdom". ${ }^{63}$ The Haram-al-Sharif (Temple Mount) with its Muslim sanctuaries was now the residence of the Frankish administration and the Knights Templar. A gilded cross on top of the Dome of the Rock clearly signalled the identity of the new rulers, who anachronistically named it Temple of the Lord, Templum Domini. Moreover, the Latins rebuilt the churches that were destroyed under Fatimid rule at the beginning of the eleventh century. They even erected a number of new ones within the walls, and also in the Kidron Valley and on the Mount of Olives. The most

60 Chapter 6 (Pål Berg Svenungsen), 95-131. Svenungsen thereby challenges the historiographical tradition, which generally has been reluctant to consider Norse expeditions to the Eastern Mediterranean as proper crusades.

61 Chapter 5 (Øystein Ekroll), 86-93.

62 Chapter 10 (Anthony Bale), 191-97. Ane L. Bysted and Maria H. Oen also discuss pilgrims' emotional responses in their respective chapters.

63 Adrian J. Boas, Jerusalem in the Time of the Crusades: Society, Landscape and Art in The Holy City under Frankish Rule (New York - London: Routledge, 2001), 1. 
prestigious undertaking in Jerusalem during crusader rule was, however, the refashioning of the Church of the Holy Sepulchre, inaugurated in 1149. It ingeniously encompassed the entire precinct of passion sites: the Calvary, the Sepulchre, the prison of Christ etc. On the floor in the middle of the building, there was an inlaid ornament called the omphalos (navel), a spot marking out the midpoint of the world. ${ }^{64}$ In an itinerary presenting the route from Northern Iceland via Rome to Jerusalem, written shortly after 1150, the Icelandic abbot Nikulás Bergsson (d. 1159) describes the crusaders' newly restored church. ${ }^{65}$ He was part of a growing influx of pilgrims around the middle of the twelfth century, for which the Frankish authorities provided lodgings and other facilities. Accounts from Scandinavian pilgrims and crusaders shed light on the condition of Jerusalem's sanctuaries and infrastructure during this period, as Denys Pringle shows in his contribution to this book. ${ }^{66}$

The Latin Kingdom of Jerusalem suffered, however, from internal conflicts, weak leadership, and increasingly bad relations to its Muslim neighbours. The spectacular failure of the Second Crusade in 1149 undoubtedly embittered the inauguration of the Church of the Holy Sepulchre the same year. Internal struggles continued and intensified in the following decades, bringing the kingdom on the verge of civil war. This was the situation in July 1187, when a unified Muslim army under command of the Kurdish warlord Saladin (Salāh ad-Dīn Yūsuf ibn Ayyūb, 1138-1193) vanquished the Latins at the battle of Hattin in Galilee. In October the same year, Saladin entered Jerusalem, tore down the city walls and the cross at the Dome of the Rock, erased the Christian structures at the Haram, closed a number of churches and monasteries and introduced an entrance fee for Christian pilgrims to the Holy Sepulchre. ${ }^{67}$ He refrained, however, from killing the defeated Christians. A Danish-Norwegian expedition had set out for the Third Crusade in 1187, but came too late and found Jerusalem in Saladin' hands. An account of their journey, probably written at the Premonstratensian monastery in Tønsberg, Norway in the 1190s, laments the western loss of the Holy City. In her chapter, Ane L. Bysted offers a brief but careful reading of this text, pointing out its allusions to the biblical topos of Jerusalem desolata, and showing how the journey to Jerusalem, although failed as crusade, still earned glory and legitimacy for the aristocrats who took part.

After a highly pragmatic treaty between the Sultan of Egypt, Al-Kāmil (1177-1238) and the Holy Roman Emperor Frederick II (1194-1250), Jerusalem was restored to the

\footnotetext{
64 Joyce Hill, "From Rome to Jerusalem: An Icelandic Itinerary of the Mid-Twelfth Century," Harvard Theological Review 76, no. 2 (1983): 194; Robert Ousterhout, "Architecture as Relic and the Construction of Sanctity: The Stones of the Holy Sepulchre," Journal of the Society of Architectural Historians 62, no. 1 (2003): 11.

65 Nikulás' text is examined in Chapter 11 (Denys Pringle), 203-7 and Chapter 12 (Stefka G. Eriksen), 219-43.

66 Chapter 11 (Denys Pringle), 198-217.

67 Boas, Jerusalem in the Time of the Crusades, 18.
} 
Latins for a short intermezzo of ten years. In 1244, however, Frankish rule in Jerusalem ended for good, despite subsequent crusade expeditions from the West. King Louis IX of France (1214-1270), the later saint, conducted yet another unsuccessful crusade 1250-54. At least, he carried home the prominent relic of Christ's crown of thorns from Constantinople, and had the Sainte-Chapelle erected in Paris as a precious reliquary to house it. Later, spines from the crown of thorns were donated as royal gifts to kings and clergy in Norway and Sweden, connecting Scandinavia to Jerusalem via a geopolitical detour to France. ${ }^{68}$

There are also some sporadic sources of Scandinavians travelling in Syria and Palestine in the turbulent time following the Mongol sack of Baghdad in 1258 and subsequent Mongol expansion westwards into Syria. ${ }^{69}$ The Mongols, and their Christian allies in the remaining crusader state of Antioch, were defeated by the Mamelukes, who had recently risen as a new political power at the expense of the Ayyubid sultanate founded by Saladin. ${ }^{70}$ A fragmented itinerary is preserved, written by Maurice, a Norwegian Franciscan, who arrived in Palestine from Western Norway shortly after the Mameluke leader Baybars (1223-1277) had captured the crusader fortress Crac des Chevaliers in 1271. The friar was part of the entourage of the nobleman Andres Nikulasson, who never returned from the expedition. ${ }^{71}$ The Swedish chronicler Olaus Magnus (1490-1557), writing in the early sixteenth century, reports that several pilgrims, among them a number of women, went to Jerusalem from Sweden in the last decades of the thirteenth century. ${ }^{72}$

Acre, the last Latin stronghold in the East, fell to the Mamelukes in 1291. Christian rule in Palestine ended for good, and from this time on, Western pilgrims, among them some Scandinavians, had to obtain permission to visit The Holy Land. When they arrived in Jerusalem, they entered a vulnerable city with no walls around it. The walls of Jerusalem had come down during Saladin's conquest and were not yet rebuilt, as the Mamelukes found the city's strategic importance too small to give priority to its fortifications. ${ }^{73}$ In Jerusalem, the pilgrims were under the guidance of the Franciscans, appointed by the Pope as custodians of the Holy Land. The Franciscans served in the Holy Sepulchre, and in 1300, they installed themselves on Mount Sion, where they hosted pilgrims arriving from the West. ${ }^{74}$ One of the Scandinavian visitors was the noblewoman Birgitta of Sweden

68 Lena Liepe discusses these royal gifts of Jerusalem relics in Chapter 9, 167-8 and 170-3.

69 For an overview of the sources, see Paul Riant, Expéditions et pèlerinages des Scandinaves en Terre Sainte au temps des croisades (Paris: impr. de A. Lainé et J. Havard, 1865-1869), 368-72.

70 Thomas F. Madden, The Concise History of the Crusades (Lanham: Rowman \& Littlefield, 2013), 174.

71 See Chapter 11 (Denys Pringle), 211. The route of Friar Maurice is visualized in Fig. 11.6.

72 Olaus Magnus, Historia de gentibus septentrionalibus, Rome, 1555 (Liber VI, Cap. 19).

73 Armstrong, Jerusalem: 304.

74 Valentina Covaci, "Between Traditions: The Fransicans of Mount Sion and their Rituals (1330-1517)" (PhD Thesis, Amsterdam University, 2017). For Scandinavian pilgrims in Jerusalem 
(1303-1373), celebrated visionary and ardent political activist. Arriving as a pilgrim to the Holy Land in 1370, ageing Birgitta experienced that the ultimate truth of the mysteries of Christ could only be known in situ, Maria H. Oen argues in her chapter. ${ }^{75}$ Birgitta's authority was considered so great at the time and in the years that followed that her visions of Christ's nativity in Bethlehem and his crucifixion in Jerusalem came to have lasting impact on visual representations of these events. ${ }^{76}$

From the fourteenth century on, the Franciscans in Jerusalem had the privilege to bestow knighthood on behalf of the Order of the Holy Sepulchre. This order had existed since the time of the crusader kingdom, originally attached to Augustinian Canons Regular. A considerable number of Western aristocratic pilgrims were knighted in the Church of the Holy Sepulchre during the fourteenth and fifteenth centuries. Among them was Erik of Pomerania (1382-1459), who followed Queen Margrethe (1353-1412) as regent of all three Scandinavian kingdoms. ${ }^{77}$ In in 1453, six years before Erik's death, the Ottomans conquered Constantinople and eliminated the once glorious Byzantine Empire. This new power rising in the East was to open a new chapter in the history of Jerusalem. In December 1516, the sultan of the Ottomans, Selim I (1470-1520), took over the city without opposition from the inhabitants. The beginning of Ottoman rule in Jerusalem in 1517 coincided with religio-political events in Germany connected to the Augustinian friar Martin Luther. These events came to have wide-ranging consequences and eventually transformed Scandinavian ideas about Jerusalem's significance. This, however, is the subject of the subsequent volume of this series.

\section{Phases in the Mediation of the Jerusalem Code in Medieval Scandinavia}

The brief overview given above of Scandinavians travelling to Jerusalem and the Holy Land from $c .1000$ to $c .1500$ covers an era of enormous change in the travellers' domestic societies. The historical development of medieval Scandinavia is not rectilinear or uniform in this period. On the contrary, there are large regional and national differences across the geographical area that this book covers. Political

from the late fifteenth and sixteenth century, see Janus Møller Jensen's chapter in Tracing the Jerusalem Code, vol. 2, 198-231.

75 Chapter 13 (Maria H. Oen), 245-67.

76 See for instance Mary Dzon, The Quest for the Christ Child in the Later Middle Ages (Philadelphia PA: Pennsylvania University Press, 2017), 186-245; Maria H. Oen, "Iconography and Visions: St. Birgitta's Revelation of the Nativity of Christ," in The Locus of Meaning in Medieval Art: Iconography, Iconology, and Interpreting the Visual Imagery of the Middle Ages, ed. Lena Liepe (Kalamazoo MI - Berlin: Medieval Institute Publications, 2019).

77 On Scandinavian nobles knighted by the Franciscans, see Eivor Andersen Oftestad's introduction to Tracing the Jerusalem Code, vol. 2, 12-48. 
alliances and conflicts between the Scandinavian kingdoms themselves, and with their neighbouring powers, shifted through these centuries. Still, when it comes to the workings of the Jerusalem code, it is possible to discern some chronological phases that largely seem to apply to the whole of this northernmost part of Europe.

The earliest sources mentioning Jorsalir, the Old Norse term for Jerusalem, dates from eleventh-century Norway and Sweden. As Klaus Johan Myrvoll conveys in his chapter on etymology in the introductory part of this book, these vernacular sources clearly refer to the actual city in the Holy Land, either as pilgrimage goal or as a desired destination of conquest. ${ }^{78}$ The Latin derivate of Hebrew Hierusalem (Jerusalem), however, was inherently multivalent. The term must have become familiar to Scandinavians through liturgical texts and practices from the earliest missionary period. In the liturgy and readings of the Holy Mass and in the Divine Office of the monastic orders, Jerusalem permanently oscillates between the historical city of the Jews and multiple meanings of allegorical exegesis. ${ }^{79}$ This ambiguity is explicated in exegetical commentaries, for instance in some of the vernacular homilies preserved from twelfth-century Norway. ${ }^{80}$ Indeed, the interpretative dynamics embedded in the metaphorical cluster we call the Jerusalem code was nurtured by the continuous ritual repetition of the Golgotha event not only during Easter, but also in every single Eucharistic celebration. Hence, the liturgy and the church buildings designed to surround it must have been the primary media of the Jerusalem code in Scandinavia in the tenth and eleventh centuries.

During the first half of the twelfth century, the church of the North was consolidated. Rome established three Scandinavian archbishoprics (1104: Lund; 1154: Nidaros; 1160: Uppsala), and eventually, a fixed network of parishes emerged

78 Chapter 2 (Klaus Johan Myrvoll), 42-7.

79 Cf. Prelude, 5-6. Liturgical sources from the missionary period in Scandinavia are non-existent. Obviously, the early liturgy was highly influenced by use in the homeland of the missionaries, who came from England to Western Norway and from the German Empire to Denmark and Sweden. The first monastic foundations seem to have been established in the last decades of the eleventh century or around 1100. Most preserved missals, breviaries and handbooks for the Liturgical Hours preserved in Scandinavia date from the late middle ages. Liturgical commentaries (expositiones missae) are however preserved in vernacular manuscripts from ca. 1200 to ca 1400, cf. Messuskýringar. Liturgisk symbolik frå den norsk-islandske kyrka i millomalderen, ed. Oluf Kolsrud, Oslo: Kjeldeskiftfondet, 1952; Messuskýringar, trans. Elise Kleivane, ed. Sigurd Hareide, et al., Oslo: St. Olav forlag, 2014.

80 One example is found in the homily for the feast of the circumcision of Jesus (January 1): "Fyrir pví at sva sem forðum varo born borem í mysteri î Ierusalém með fornom eptir scurðar-skrin, sva ganga litillatir in himnesca Iersualém með fornom goðra værca skirðir ok skilðir fra ollum dæuðlegum ustycðum á domsdæigi”[Just like the children in olden days were carried into the temple of Jerusalem with offerings after their circumcision, thus will the humble enter the heavenly Jerusalem on Domesday with the offerings of their good works, purged and parted with all deadly deficiencies,] Gamal norsk homilebok: Cod. AM. $6194^{\circ}$. Edited by Gustav Indrebø. Oslo: Kjeldeskriftfondet, 1966, 54. This and other homilies are compiled in AM 619 4to, a manuscript from $c .1200$. The Old Norse texts, however, are dated to the twelfth century. 
across these northern church provinces. The cathedral chapters and the numerous monastic foundations fostered a prolific literate culture, providing abundant rhetorical occasions for the application of the Jerusalem code: new literary genres, new liturgical celebrations, and new architectural schemes. Additionally, iconography and ornamental forms in liturgical objects, church architecture, and ecclesiastical furnishings were finely tuned to manifest the relevance of multivalent Jerusalem to the Scandinavians, as several of the chapters in this book show. ${ }^{81}$ An ambitiously rapid building of churches radically transformed the Northern landscapes during the long twelfth century. This "mantle of churches" covered most of the Scandinavian territories, and though most of them were of modest size, their design tended to conform to what Line M. Bonde in her chapter labels "architectural commonplaces," constituting small connecting points to the heavenly Jerusalem scattered about all of Scandinavia. $^{82}$

Within the highly ritualized and solemn space of the parish churches, Jerusalem was actualized sacramentally during the liturgy of the Holy Mass, in the mystical communion between Christ and his bride, the church, daughter of Zion. A particularly striking visualization of this is the sumptuous gilt altar from Lisbjerg Church in Jutland, Denmark, made in the 1130s (Fig. 1.3). The ensemble of altar frontal and arched retable has a strong Christological axis, on which one of several focal points is the Virgin enthroned with the Christ Child under an arch with the inscription CIVITAS HIERUSALEM. Here, the Virgin is construed as the entrance to the City of God. The altar displays a sophisticated interplay between composite iconography and a selection of Latin metric verse inscriptions along the frames. Together, texts and images communicate a soteriological message in which the multivalence of Jerusalem is constitutive. ${ }^{83}$

Although the erudite subtleties of the theological message in furnishings like the Lisbjerg altar probably was lost to most parishioners coming to church, it was hard to miss the centrality of Jerusalem in liturgical performance. This was especially true of rituals connected to the individual lives of parishioners, like the Churching of women after childbirth, which is the topic of Margrete Syrstad Andås'

81 For the concept "rhetorical occasion" in this context, see Kristin B. Aavitsland, "Elite Soldiers of Christ: Elevating the Secular Elite on Danish Church Walls (Twelfth to Thirteenth Centuries)," in Nordic Elites in Transformation, c.1005-1250. Volume III: Legitimacy and Glory, ed. Wojtek Jezierski, et al. (Routledge, 2021), 175-202.

82 The case of Denmark is especially noticeable: here, more than 3000 stone churches were built, decorated, and sumptuously equipped in the course on one single century, cf. Chapter 15 (Line M. Bonde), 299-323.

83 Kristin B. Aavitsland, "Civitas Hierusalem: Representing Presence in Scandinavian Golden Altars," in Image and Altar 800-1300. Papers from an International Conference in Copenhagen 24 October - 27 October 2007, ed. Grinder-Hansen (Copenhagen: National Museum Studies in Archaeology and History, 2014), 189. 


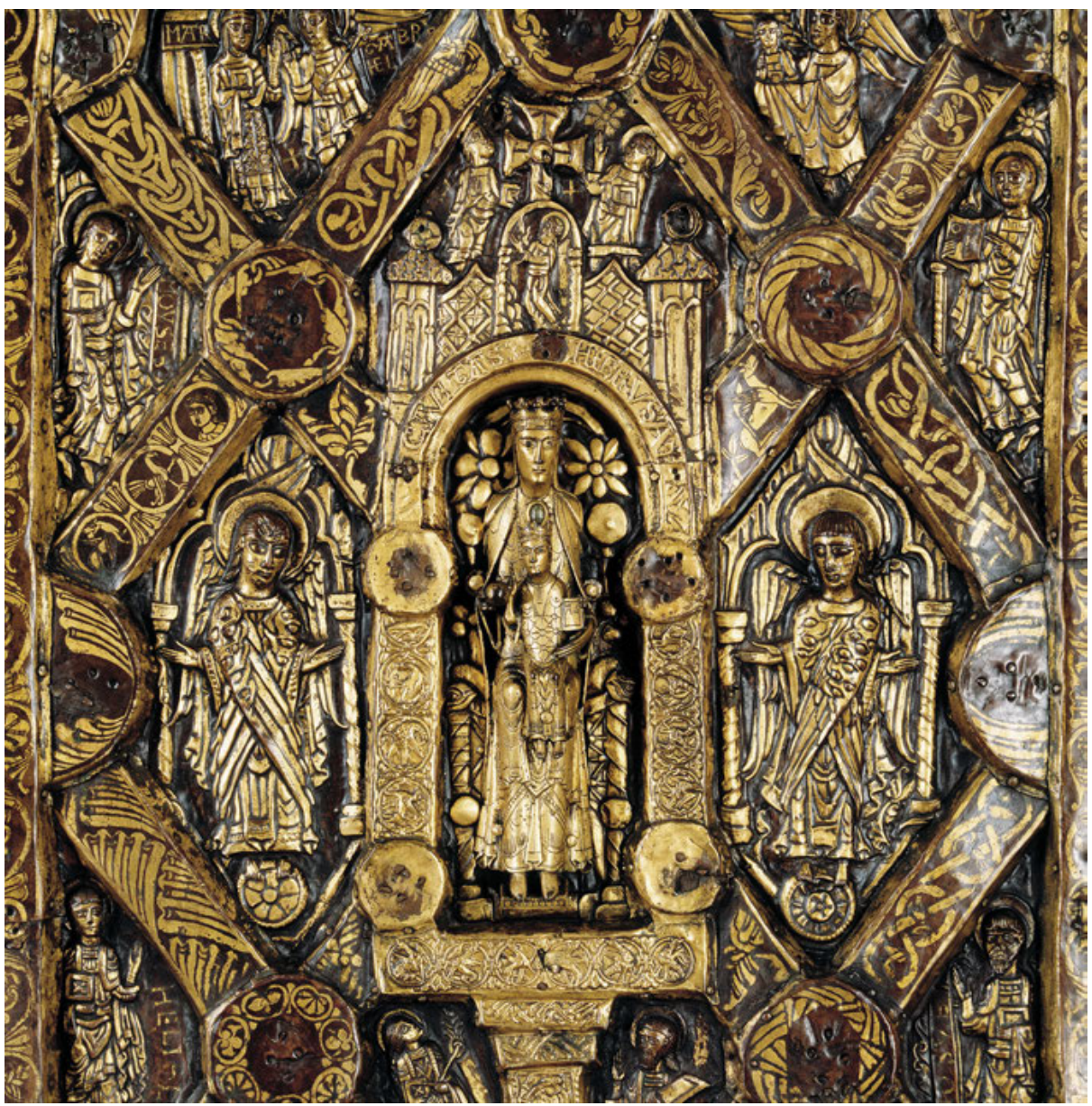

Fig. 1.3: Civitas Hierusalem. Central part of the gilt altar frontal from Lisbjerg Church, 1135. Nationalmuseet, Copenhagen.

chapter in this book. ${ }^{84}$ Entering the church as mothers post partum just like the Virgin Mary once had entered the Temple, they were themselves to perform rites that explicitly enacted Jerusalem, simultaneously as biblical past, transcendent present and eschatological future. Liturgy, church decoration, and architecture continued to have greater impact on the formation of a Christian storyworld than the written media, whose circulation was exclusive and rather limited.

84 Chapter 17 (Margrete Syrstad Andås), 340-74. 
The Jerusalem code was, however, never restricted to liturgical space. From the very beginning, ideology-makers like royal skalds (court poets) and chroniclers readily applied the metaphors, narratives, and performative templates of the Jerusalem code for political purposes. Simultaneously, political and societal dimensions added to the meaning production of the liturgy. This cross-fertilization between political and liturgical workings of the Jerusalem code seems to increase during the twelfth and early thirteenth centuries, when the Scandinavian kingdoms gradually developed more stable and professional state administrations, in parallel with the consolidation of ecclesiastical culture. Since the emergence of a literate culture in Scandinavia largely coincided with the heyday of crusade, the connection to Jerusalem was not only vertical and heaven-bound, but also horizontal. The Northerners were to reshape their past and find their place in Christendom at a point when Christians were obliged to expand its realm, fight its enemies, and defend the faith with armed force. In Scandinavia, whose pre-Christian culture had held the figure of the warrior in particularly high regard, this concept of Christian identity seemed to take root in fertile soil. ${ }^{85}$ Crusading became a vital dimension of Jerusalem reception in Scandinavia, in ideology as well as in practical politics. The archiepiscopal see at Lund was founded only five years after the Franks' conquest of Jerusalem in 1099. According to Kurt Villads Jensen, the rise of Lund to the rank of archbishopric was closely connected to the Danish king Erik the Good's crusade to Jerusalem in $1103 .{ }^{86}$ As mentioned above, King Erik's Norwegian counterpart, King Sigurd the Crusader, went to Jerusalem few years later, and aimed to establish a Norwegian archbishopric in Nidaros. Although this ambition was not fulfilled until 1154, the fact remains that from the early twelfth century and onwards, references to Jerusalem appeared as legitimation strategy for royal authority and for an expansive foreign policy.

A conspicuous instance of theological legitimation of secular politics dates from the reign of Valdemar II of Denmark (r. 1202-1241), whose successful campaign to extend Danish territory into the Baltic earned him the epithet "the Victorious" [Valdemar Sejr]. The cathedral of the Valdemar dynasty's preferred residence town, Ribe in southwestern Jutland, carries a remarkable and much-discussed triangular relief above the portal of the southern transept (Fig. 1.4). The relief is added on top of the tympanum representing the Deposition of Christ, exhibiting an iconography not known from any other sources: below a portal with the inscription Civitas Hierusalem is Christ and the Virgin Mary, enthroned as the King and Queen of Heaven. Christ is passing a cross to the Virgin, who is passing it on to an earthly king, standing below her, with his earthly queen by his side. The two couples mirror each other - like the sovereignty of earthly princes was to reflect the royal dignity of Christ. The exchange of crosses must, I think, be interpreted as a transfer of authority: Christ, the Lord for ages of ages (alpha and

85 Aavitsland, "Defending Jerusalem," 128.

86 Jensen, Crusading at the Edges of Europe, 112. 


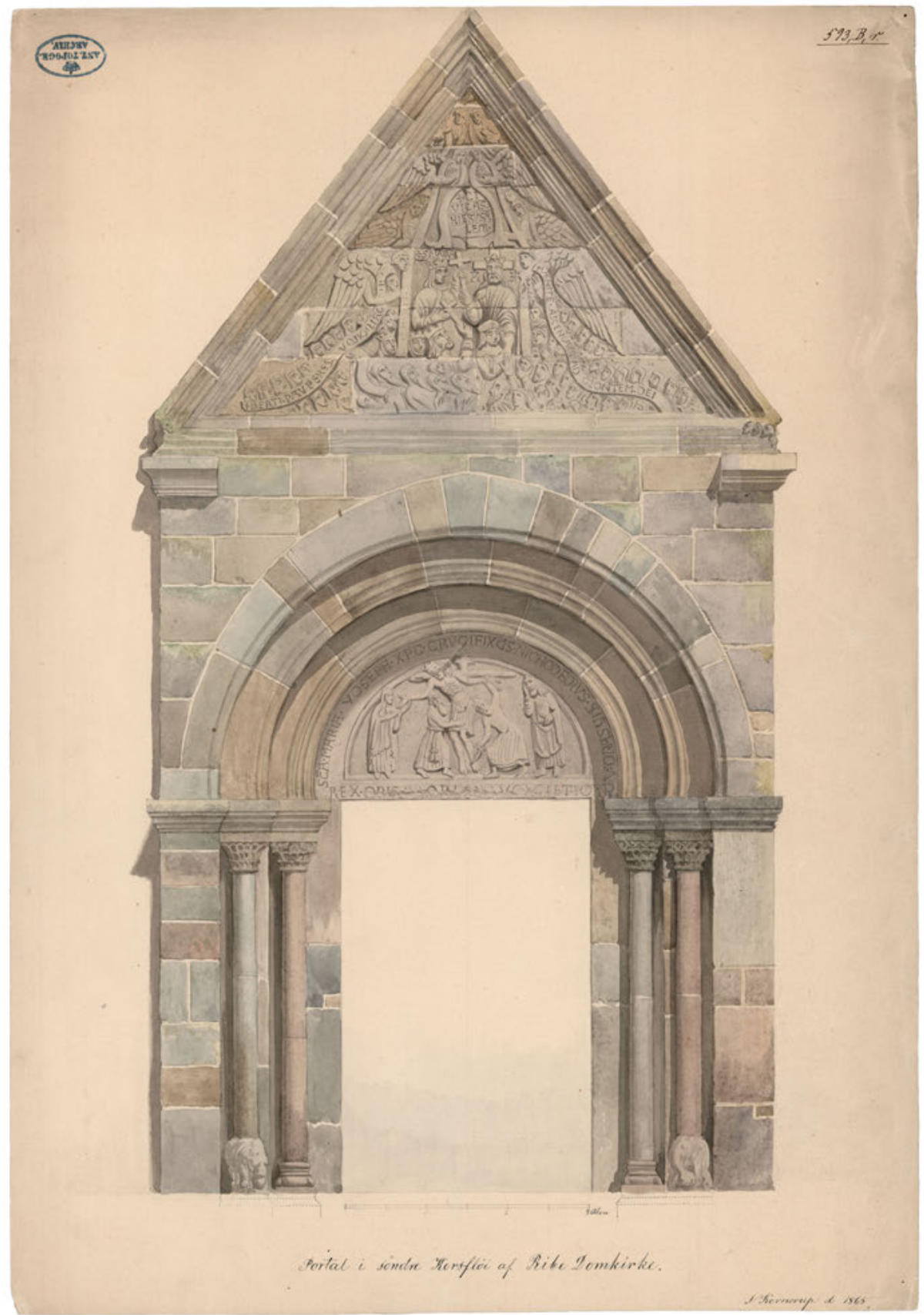

Fig. 1.4: Taking the cross for Jerusalem. Relief above the portal of the southern transept, Ribe Cathedral, early thirteenth century. Watercolour by J. Kornerup, 1865. Nationalmuseet, Copenhagen. 
omega) authorises his bride, depicted as the Virgin and representing the Holy Roman Church, to take the cross. The church in her turn authorizes the secular ruler. Although the interpretation of this relief is debated, scholars largely agree that the king is meant to portray Valdemar II, whereas the beardless man on the right is generally held to be St Knud Lavard, the Danish crusader saint. ${ }^{87}$ Around the group are hailing angels, carrying long, inscribed ribbons. The inscription to the right alludes to the beatitudes of the Sermon on the Mount (Matt 5:3): Beati pauperes (s)(piri)tu quoniam (regnum dei) possidebitis [Blessed [are] the poor in spirit, for you shall possess the kingdom of God]. The angel to the left carries a quotation from the prophet Isaiah: Venite ascendam(us) ad montem Dei [Come ye and let us go up to the mountain of the Lord] (Isa 2:3). These two selected biblical quotations connect the claim for the heavenly kingdom with the mountain of the Lord - Mount Zion, i.e. Jerusalem. In the relief, Civitas Hierusalem is clearly meant to represent the transcendent glory in the heavenly city. But against the background of the royally authorized, contemporary crusading campaigns on the Baltics, a political dimension is also close at hand.

Crusading ideology lived on through the entire medieval period, and the idea of meritorious and just war against Muslims and heathens continued to inform political and religious thought also after the Protestant reformation in the sixteenth century. However, during the thirteenth and fourteenth centuries, other aspects of the Jerusalem code than crusade and holy war seem to be more prominent in written, visual, and built sources. The royal courts, cathedral chapters, and religious houses encouraged learning, and continental texts were increasingly circulated, translated, and commented on in parallel with the rise of an indigenous literary production, both in Latin and the vernacular. Corresponding to this gradually sophisticated literate culture was the accomplishments in painting, sculpture, and architecture, the enhancement of liturgy, and the codification of law. In all these endeavours, Jerusalem is not so often referred to as the legitimate, territorial bequest of Latin Christianity, but rather construed as a model for a true Christian society to be fulfilled in the transcendent glory ahead of humankind. The fourteenth-century Icelandic manuscripts under discussions in the chapters by Stefka G. Eriksen and Kristin B. Aavitsland testifies to a culture in which Jerusalem is a moral compass and a depository of material for spiritual edification, suited for monastic rumination. ${ }^{88}$ During the era of the Kalmar union (1397-1523), which united the three kingdoms of Denmark, Sweden (including most of Finland) and Norway (including Iceland) under one single monarch, individual penance and contemplation of Christ's passion and death at Golgotha were increasingly significant features of lay devotional practices. This process prompted renewed devotion to The Holy Cross, as

87 Ane Bysted et al., eds., Jerusalem in the North: Denmark and the Baltic Crusades, 1100-1522 (Turnhout: Brepols Publishers, 2012), xiii.

88 Chapter 12 (Stefka G. Eriksen), 218-43, Chapter 20 (Kristin B. Aavitsland), 424-53. 
Kaja Merete Hagen shows in her chapter, and came to transform the representations of Jerusalem in ecclesiastical spaces, as Martin Wangsgaard Jürgensen demonstrates in his. ${ }^{89}$

During the fifteenth century, the expanding Ottoman Empire affected the Christian storyworld. With the Otttoman conquest of Constantinople in 1452, the Scandinavians' dream of Miklagard came to an end. Forty years later, Christopher Columbus set foot on a continent unknown to the medieval world. The kringla heimsins seemed to expand - also from a Scandinavian point of view. In the wake of Spanish expeditions to the new world, King Christian II of Denmark-Norway (1481-1559) planned to lay claim to the North American continent and urged for a crusade to Greenland. ${ }^{90}$ This ambition proved, however, to be one of the dead ends of history. The expansion of the Christian storyworld to new continents in the sixteenth century seemed to imply, however, a transformation - or perhaps rather an implosion - of the storyworld as it was conceived of in the Middle Ages.

\section{The Authority of Jerusalem in Medieval Scandinavia: An Outline of this Book}

This book explores the authority of Jerusalem in medieval Scandinavia through four main themes: legitimation of political power, experience and perception of sacred topography, formulation of and interaction with sacred space, and acknowledgment of the scheme of salvation history. These four themes largely correspond to the four parts of the book. Still, the themes are intertwined, and thus addressed in most of chapters. Chapters come in two forms: as brief, explicatory comments on key concepts and short presentations of source material offering illustrative cases for such concepts, or as more comprehensive research papers. Together, the chapters present textual, visual, and material sources from Denmark, Sweden, Norway, and Iceland, and cover a time span from the turn of the first millennium up to the early sixteenth century. There is, however, an emphasis on the twelfth and thirteenth centuries, and a majority of the chapters centre on Norway.

Following this introduction are two shorter introductory texts (Chapters 2 and 3): Klaus Johan Myrvoll's brief chapter on the Old Norse term for Jerusalem, Jorsalir, and its application and associative etymology, followed by Eivor Andersen Oftestad's presentation of the fundamental concept of translation templi.

The main theme in Part I (Chapters 4-9) is legitimation of political power by means of Jerusalem's authority. When investigating religious and political authority

89 Chapter 18 (Kaja Merete Hagen), 373-93; Chapter 19 (Martin Wangsgaard Jürgensen), 394-421. 90 Janus Møller Jensen, Denmark and the Crusades, c.1400-1650 (Leiden: Brill, 2007). 
in medieval Scandinavia, representations of saintly kingship looms large. Bjørn Bandlien examines the literary representation of St Olav's entry as a Christian king to his realm, and Øystein Ekroll offers a brief introduction to the paintings of St Olav and St Knud in the Church of the Nativity in Bethlehem. Pål Berg Svenungsen and Ane L. Bysted examines sources to Scandinavian crusading to the Levant, whereas Lukas Raupp and Lena Liepe survey relics connected to the Passion of Christ arriving in Scandinavia during the Middle Ages, showing how this holy matter ultimately deriving from Jerusalem played fundamental political roles in the three Scandinavian kingdoms.

Part II (Chapters 10-13) considers pilgrimage to Jerusalem and the travellers' perceptions of and interactions with the Holy City. Anthony Bale discusses the informal, yet ritualized behaviour of Western pilgrims when laying eyes on their sacred destination, be it Jerusalem or Nidaros. Denys Pringle gives a thorough presentation of sources accounting for Northern visitors to Jerusalem and the Holy Land in the twelfth and thirteenth centuries up until the fall of Acre in 1291. Stefka G. Eriksen examines one of them in greater detail: Abbot Nikulás of Munkathvera's itinerary from c.1150. Part II closes with Maria H. Oen's chapter on the most influential of Scandinavian Jerusalem pilgrims of all time, St Birgitta of Sweden, and her highly influential visionary perceptions of Jerusalem's loca sancta.

Part III (Chapters 14-19) offers examples of how Jerusalem was transposed and represented architecturally, iconographically, and liturgically in medieval Scandinavia. Øystein Ekroll, Kersti Markus, and Line M. Bonde consider Jerusalem connotations in cityscapes, landscapes, and ecclesiastical architecture in twelfthcentury Norway, Sweden, and Denmark respectively. Margrete Syrstad Andås and Kaja Merete Hagen study lay devotional practices re-enacting Jerusalem events in late medieval Norway and Sweden, whereas Martin Wangsgaard Jürgensen describes a transition in Jerusalem representation in ecclesiastical ornamentation from the Romanesque to the Gothic paradigm.

Part IV (Chapters 20-24) concerns outlooks from the North onto a world in which Jerusalem is the undisputable symbolic centre and the inherent aim of history is Christ's salvation of humankind. Kristin B. Aavitsland examines how Jerusalem is the structuring principle in three fourteenth-century encyclopaedic manuscripts from Iceland. Mikael Males investigates means by which the temporal and spatial distance between thirteenth-century Iceland and biblical Jerusalem were negotiated in Old Norse literature. Margrethe C. Stang discusses visual representations of outsiders to the Christian storyworld of the medieval North: the Jews, the Muslims, and the Saami. Jørn Øyrehagen Sunde shows how the Christian virtues, exegetically connected to the Heavenly Jerusalem, are comprehensively applied as orientation marks in the Norwegian Law Code of 1274. The volume closes with Biörn Tjällén's study of the identification of archiepiscopal Uppsala with Zion in late medieval Swedish historiography. 